\title{
Epicurean Primitivism: An Analysis of Lucretius On the Nature of Things Book 5
}

\section{Larry J Waggle \\ Illinois State University}

In the Greek tradition of political thought, one alleged political theory stands apart from the rest, namely the one expounded by Epicurus and his followers. It is generally held that Epicurus and the Epicureans did not have a political theory, and that Epicurus sought refuge from the turmoil of political life by retreating into his school. In place of political life, Epicureans formed a small society of like-minded friends. This view of Epicurus' social theory, I shall argue, is fundamentally misguided. One impact of this understanding of Epicurus' doctrines has led scholars to disregard many of the important sayings by Epicurus with respect to political justice, and on account of this, we face a fundamental misunderstanding of Epicurus' overall social theory. For the purposes of this paper, I shall focus on the so-called Epicurean primitivism. I shall argue that, in spite of some of the Epicurean sayings that might suggest otherwise, Epicurus does have an interest in politics, and the alleged Epicurean primitivism is unfounded.

Some of the evidence used to support the primitivist thesis is the emphasis Epicurus places on friendship, which has led some commentators to believe that he rejected society altogether. In conjunction with a passage from Diogenes of Oenoanda ${ }^{1}$, which refers to a utopian time when the life of the gods will pass to men, ${ }^{2}$ implies that the Epicureans had no real interest in political justice. Further, the Epicurean motto "Live Unknown" has led many commentators to believe that Epicurus advocated some "back to nature' or some primitivism in social arrangements, or even a rejection of society altogether. This view has been championed by Benjamin Farrington who, in The Faith of Epicurus, argues that the Epicurean Garden resembles the primitive 'city of pigs' described by Socrates in Book 2 of Plato's Republic. Farrington envisions the Epicurean community to be a form of society where 
the state has "withered away." Farrington writes "only the simple form of the state was 'natural', for this was held together by the natural impulse of friendship. The fully-developed state, with its code of laws enforced by external sanctions, was not natural to man."3 This interpretation is a good example of the so-called primitivist interpretation of Epicurus' social views. This interpretation, however, fundamentally misunderstands the nature of friendship and oversimplifies and obscures the commitment Epicureans have for political justice. The primitivist often consider Epicurus' overall social theory to be something like a quietist movement. That is, in order to obtain the Epicurean telos, tranquillity, one should not draw attention to oneself. The best way to not draw attention to oneself is to withdraw into a community of like-minded individuals and live withdrawn from the rest of society.

For the purposes of this paper, I do not have the time to explore the totality of Epicurean social theory. ${ }^{4}$ Instead, I shall argue against the primitivist thesis by carefully examining the longest treatment of the origin of human society remaining from the Epicurean corpus: namely, Lucretius' On the Nature of Things, Book 5. The last third of this book has been used to support the so-called primitivism. In order to defend my position, I will need to demonstrate that there is in fact a concern in Epicurus' social theory for political justice. As James Nichols ${ }^{5}$ has pointed out, there is a fundamental objection often raised in connection with Epicurus' social theory. That is, that Epicurus has no political philosophy. Nichols correctly notes that there is nothing in the remaining Epicurean manuscripts of a political teaching like the one found in either Plato's or Aristotle's works. There is no discussion of what the simply best regime would be, nor of what the practically best regime would be in various circumstances. In addition, there are a number of Epicurean teachings that would seem to be altogether hostile to politics as such and to urge men to avoid public life altogether. Epicurus' work on justice was lost. ${ }^{6}$ In its absence, many of the anti-political sayings have been used to suggest that Epicurus rejected society and hence advocated some form of primitivism in human social arrangements. 
Contrary to this interpretation, I maintain that Epicurus does have a political philosophy, and in particular an interest in the political notion of justice. I agree with Nichols' observation that the heart of Epicureanism is above all a teaching about human life and how men can lead the best possible life, and what kind of knowledge they must have in order to do so. For Epicurus, ethics takes precedence over physics, and our theoretical knowledge is, in the end, subordinated to the needs of ethics in order to make happiness possible. Nichols argues that since most men live together with others in political society, a crucial part of any philosophy whose goal is happiness must be concerned with man's relation to other men, which is to say, with politics. Nichols notes that political society makes claims on its members. The whole political framework of laws, beliefs, and conventions has a regulative effect of the members of the political community. Someone concerned with the best way to live must therefore come to a clear understanding of political society, which seems to be essentially constituted by its justice, by its claim to be just, to promulgate and enforce just laws, decrees and decisions. It is no small accident, then, that there are a substantial number of the Kyriai Doxai that discuss the nature of justice and its relationship to law. These sayings must be taken into consideration with the anti-political sayings. As Nichols has pointed out, the claims that political society makes on its members have a regulative effect on the members of that society. This regulative effect could be either beneficial to the goal of ethics or hostile to that goal. Hence, I tend to read these anti-political sayings as suggestive of a reformative element in Epicureanism. This places Epicurus in the arena of being a social reformer, not in the arena of rejecting society tout court.

Of the surviving Epicurean texts, the longest treatment of the origin of human social organization is found in Lucretius' On the Nature of Things, Book 5. This text has been the battle ground for the debate over whether Epicurus has or does not have a political philosophy. Various portions of this poem have been used to support the notion that Epicurus was a primitivist or that he advocated some 'back to nature' movement. What I intend to 
demonstrate, in this paper, is that there is no support in Book 5 of On the Nature of Things for the primitivist notion. This is important, because the primitivist reading of Epicurus would suggest that he does not have a social theory. In order for the primitivist interpretation to be valid, it must identify some stage in human social development where our telos was naturally expressed before society marred or obscured it. The primitivist must, therefore, identify some "golden age" in the Epicurean account of social development, that is, the stage towards which we are trying to go back to. Through a close reading of this section of the poem, I shall argue that there is no indication in the poem of an alleged "golden age" where the Epicurean notion of happiness found its natural expression before it was lost in the wake of society. If there is no portion of this poem that can be used to support the notion of this "golden age," then the primitivist interpretation must be rejected.

In the last third of Book 5, On the Nature of Things, Lucretius discusses the origin of human civilization. This account, read in connection with the motto 'live unknown,' has been used to interpret Epicurus as suggesting some 'back to nature' movement. If society is corrupt, and this corruption is the source of empty desires that prevent one from obtaining happiness, then a return to an asocial state would seem to be the proper course of action. Because we lack any extended texts from Epicurus on justice, many of his saying have been interpreted in this manner. Also, because of the Epicurean communalism and the historical fact that many of the Epicureans lived in small, relatively self-contained communities or Gardens, these facts have lent credibility to this interpretation.

I maintain, in spite of the fact that the Epicurean school was named the Garden, and in spite of its communalism, the 'back to nature' interpretation fails to account for both Epicurus' sayings on justice and the Lucretian account of the condition of primitive human beings. If we find no indication in the section on the origin of human civilization of a so-called "golden age" in the Book 5 materials, then the primitivist interpretation must be rejected. In place of the primitivist interpretation, I would suggest that these 
passages indicate the origin of socially conditioned desires. It is, for the most part, those desires that fall into the Epicurean category of "empty" desires that are the focus of Epicurus' larger project.

Let us now turn to the evidence found in Lucretius. Lucretius' description of primitive humans starts at Book 5 lines 925-1010.

The human beings who lived on earth in those early days were far tougher than we are, as one would expect, seeing that they were children of the tough earth: larger and more solid bones formed the inner framework of their bodies, while their flesh was knit with strong sinews, and they were not easily affected by heat or cold or unaccustomed food or any physical malady. [(Lucretius, DRN 5. 925931) trans. Smith]

Primitive human beings had no knowledge of farming and lived off of acorns and berries provided by nature. The condition of primitive human beings was similar to that of other wild beasts.

As yet they had no knowledge of how to utilize fire or clothe their bodies in skins stripped from wild beasts. They lived in woods and mountain lanes and forests, when compelled to escape from the lashing wind and rain, sheltered their shaggy limbs among the thickets. [(Lucretius, DRN 5. 954-958) trans. Smith]

The life of primitive human beings was, in large measure, a solitary and perilous one. Because primitive people did not form societies, they were prey for other wild animals.

They were unable to look to the common interest, and had no knowledge of the mutual benefits of any customs or laws. Individuals instinctively seized whatever prize fortune had offered to them, trained as they were to live and use their strength for themselves alone. [(Lucretius, DRN 5. 959-962) trans. Smith] 
Lucretius describes these primitive human beings as being prey to 'fuming boars and powerful lions' driving them from their homes (5.984), and falling prey to attacks by wild beasts (5.990). The only interaction between primitive human beings was the result of the desire for sex. "Venus united the bodies of lovers in the woods. The woman either yielded from mutual desires, or was mastered by the man's impetuous might and inordinate lust, or sold her favors for acorns or arbute berries or choice pears" (5.963-966)

The descriptions of primitive man, at this stage, is no different from the condition of other wild beasts. Primitive man was subject to the randomness of natural forces, lack of food leading to starvation and death, and attacks by wild beasts. This primitive condition of primitive man cannot be the condition in which our (katastematic) pleasures ${ }^{7}$ can be realized because it is filled with physical discomfort. Nature was not able to supply primitive humans with the basic necessities required to satisfy the naturalnecessary desires for life. If it were, then there would be no account of starvation in this section of the poem.

Epicurus' conception of happiness requires the proper use of reason, and the condition of primitive man is not one in which reason has developed. In order to satisfy the natural-necessary desires for life, a minimal level of human society is required. Epicurus, in the Letter to Menoeceus, does not caution Menoeceus how to obtain food and drink, nor do the worries that disturb the soul take the form of how can he obtain clothing and shelter. Rather, Epicurus cautions Menoeceus about improperly conceptualizing the requirements of pleasure. When Epicurus discusses the limit to place on desire, he is not suggesting that an agent should always reject luxuries, but rather should not become fixated on obtaining luxuries.

And we believe that self-sufficiency is a great good, not in order that we might make do with few things under all circumstances, but so that if we do not have a lot we can make do with few, being genuinely convinced that those who least need extravagance enjoy it most; and that everything natural is easy to obtain and whatever is 
groundless is hard to obtain; and that simple flavors provide a pleasure equal to that of an extravagant life when all pain from want is removed. (Epicurus, Letter to Menoeceus. 130. (trans. Inwood))

One portion of this passage that I would like to emphasize is that everything natural is easy to obtain in so far as one is living in a community with other people. Epicurus' reference to barley cakes and water, in the sentence that follows this passage, are examples of simple food and drink to which an agent should become accustomed.

... and barley cakes and water provide the highest pleasure when someone in want takes them. Therefore, becoming accustomed to simple, not extravagant ways of life makes one completely healthy, makes man unhesitant in the face of life's necessary duties, puts us in a better condition for the times of extravagance which occasionally come along, and makes us fearless in the face of chance. (Epicurus, Letter to Menoeceus. 131. (trans. Inwood.))

If one were relying solely on one's own abilities to obtain these things, and not relying on a community with a division of labor and a market in which to trade foodstuffs, then one would find that fortune would more greatly affect the acquisition of these things. What I mean here is that if someone lived near a fresh water stream, and there was little threat that others, who had banded together, would attempt to prevent his access to this stream, or that the stream was subject to seasonal variation, i.e., did not dry up, then the agent would be fortunate. On the other hand, if an agent lived nowhere near a fresh water stream, then finding drinkable water would be far more difficult. Hence, the absence of any discussion of survivalist techniques in Epicurus' Letter indicate that Epicurus presupposes that Menoeceus has found a way to satisfy these basic needs by living in a community. Epicurus' concern, in this portion of the letter, is with the proper understanding of the use of external goods in relation to desire. 
The next stage in human development, according to Lucretius, commenced with the discovery of fire which is closely connected to the time when woman united with man and went to live with him in huts. Primitive man learned the advantage of cohabitation (5.1012-1014). With the birth of children coming from these initial couplings, the desire to protect woman and children motivated primitive man to make agreements with their neighbors neither to harm nor be harmed. Lucretius notes that these agreements were made by means of rudimentary communication "indicating by means of inarticulate cries and gestures that everyone ought to have compassion on the weak" (5.1021-1022). Lucretius indicates that there is a change in our nature at this stage. He discusses that human beings began to loose their toughness, and that by the use of fire, people were less able to endure the cold. This change in our nature indicates the beginning of social man, one who is capable of living with others because of the agreement neither to harm nor be harmed.

Next they provided themselves with huts and skins and fire, and woman, united to man, went to live in one [place with him. The advantages of cohabitation] were learned, and they saw the birth of their own offspring. It was then that human beings first began to lose their toughness: the use of fire rendered their shivering bodies less able to endure the cold beneath the pavilion of the sky; Venus sapped their strength; and children with their charming ways easily broke down the stern disposition of their parents. It was then, too, that neighbors, in their eagerness neither to harm nor be harmed, began to form mutual pacts of friendship, and claimed protection for their children and womenfolk, indicating by means of inarticulate cries and gestures that everyone ought to have compassion on the weak. Although it was not possible for concord to be achieved universally, the great majority kept their compacts loyally. Otherwise the human race would have been entirely extinguished at that early stage and could not have 
propagated and preserved itself to the present day. (Lucretius. DRN 5.1012-1027 (trans. Smith)).

It is at this early stage of social man that language is developed, and early social man was able to develop his reason.

And more and more every day those endowed with exceptional talents and mutual powers showed the others how to exchange their former way of life for new practices and in particular for the use of fire." [(Lucretius, DRN 5. 1106-1100) trans. Smith]

Social man was faced with ever new desires resulting from technological innovation. The desire for security for the weak led to the development of early society and the emergence of social power. Lucretius discusses how kings built cities and citadels to be strongholds and places of refuge for themselves (line 5.1110). Through the use of social power, kings distributed flocks and fields to individuals on the basis of their beauty, strength, and intellect. Soon thereafter money was invented and became a means by which these natural goods could be undermined on the belief that money is a means to security in itself.

At this point in his discussion of the development of civilization, Lucretius makes a moral observation. At line 5.11181120 , Lucretius notes that "if human beings would guide their lives by true principles, great wealth consists in living on a little with a contented mind; for of a little there is never a lack." This moral observation or moral comment is consistent with several of the sayings that we have from Epicurus on the dangers of wealth and the need to act only on those natural-necessary desires. ${ }^{8}$ The position of this moral observation or moral comment is important, because it is the first time in Lucretius' discussion of social development that he makes an Epicurean moral criticism. This remark is wedged in the middle of his discussion of wealth and the emptiness of fame and power. In the attempt to secure protection from harm for children, women, and themselves, people acted on the empty desires without the direction of the Epicurean analysis 
of the desires. Since people had not reasoned out the telos they, mistakenly, attempted to use social power to secure themselves against unreal or empty threats. The position of the moral comment is important. Lucretius is not claiming that as soon as people had made the compact neither to harm nor be harmed, they, then, enjoyed some "golden age". I find this important, because this initial stage of social man has been one of the passages used to support the primitivist thesis. Rather, what we see in the poem are various attempts to use social power to secure protection from harm are being employed by those who were able to wield it.

But people wanted to win fame and power for themselves, in order that their fortune might be based on a firm foundation and their wealth might enable them to lead a peaceful life. But all in vain; for as they strove to climb to the summit of success, they made their path perilous. And even when they reach the summit, envy, like lightning, sometimes strikes them and hurls them down into a hideous hell of ignominy; for envy, like lightning, usually blasts the highest places and all that are elevated above others. So it is far better to live peacefully as a subject than to desire the dominion of states and the control of kingdoms. Let them, then, sweat out their blood and weary themselves in vain, struggling along the narrow path of ambition, since their wisdom is derived from the mouths of others and their aims are determined by hearsay rather than by their own sensations; and such folly does not succeed today and will not succeed tomorrow any more than it succeeded yesterday. (Lucretius. DRN 5.1120-1137. trans. Smith)

The struggle for fame and power was intensified by the invention of metal smithing, and this struggle resulted in warfare. Eventually, people became weary of the struggle for sovereignty and supremacy for themselves. It is at this stage in our social development that laws and magistrates were established. Laws were established to end feuds and to rein in anger. 
Thus the situation sank to the lowest dregs of anarchy, with all seeking sovereignty and supremacy for themselves. At length some of them taught the others to create magistracies and established laws, to induce them to obey ordinances. The human race, utterly weary as it was of leading a life of violence and worn out with feuds, was the more ready to submit voluntarily to the restraint of ordinances and stringent laws. The reason why people were sick and tired of a life of violence was that each individual was prompted by anger to exact vengeance more cruelly than is now allowed by equitable laws. (Lucretius DRN 5.1141-1151. trans. Smith)

In connection with the fear of punishment, Lucretius makes his second moral observation or comment. What Lucretius goes on to say is reminiscent of several of Epicurus' sayings concerning the condition of life of the unjust person. Epicurus writes:

It is impossible for someone who secretly does something which men agreed [not to do] in order to avoid harming one another or being harmed to be confident that he will escape detection, even if in current circumstances he escapes detection ten thousand times. For until his death it will be uncertain whether he will continue to escape detection." (KD 35. trans. Inwood.)

Lucretius further elaborates the condition of the unjust person by noting that the creation of law, and its ensuing punishments, undermines the peacefulness of an unjust person.

Ever since that time fear of punishment has poisoned the blessings of life. Violence and injustice enmesh all who practice them: they generally recoil on the wrong doers, and it is not easy for those who by their actions violate the mutual pacts of peace to pass a placid and peaceful life; for even if their crime goes undetected in heaven and on earth, they are bound to fear that it will not remain 
hidden for ever. (Lucretius. DRN 5.1152 -1161. trans. Smith)

Although Lucretius uses the language of "poisoning the blessings of life,"I do not think that too much should be made of this allusion. Some commentators convinced of the primitivist interpretation have used this phrase as evidence that Lucretius recoils from political society. I think this is misguided, because Lucretius is making a point well known to Epicureans. This point is seen in Hermarchus' discussion of the role that the threat of punishment has in compelling people to refrain from harming others.

The threat of punishment is addressed to those who fail to take note of utility. For hanging over them, it compels them to master impulses which lead to inexpedient actions that are contrary to utility, and forcibly helps to constrain them to do what they should. This explains too why the legislators did not exempt unintentional killing from all punishment; they wanted to avoid giving any pretext to people who might intentionally choose to imitate acts done unintentionally, and also to ensure that such matters should not be approached with a carelessness or casualness which would have many genuinely unintentional consequences. (Hermarchus, as quoted in Porphyry On Abstinence 1.8 (trans Long)).

I take the allusion to the 'poisoning of the blessings of life' as the introduction, through the law, the threat that wrong-doers will be accountable to society for harms done. That threat hanging over the heads of those who would not otherwise restrain themselves from harming others preserves the pact neither to harm nor to cause harm, and further provides a means of preserving the protection of members of society. Likewise, the 'poisoning the blessings of life' remark is targeted at a limited audience. That is, towards those who would practice violence and injustice. Hence, this is not everyone, and, therefore, not everyone is being told that fear of punishment poisons the blessings of life. 
The remainder of Book 5 describes the development of religion, how the technical development of metal smithing was used both in warfare and in farming, and the invention of the crafts: weaving and the arts in general, music in particular. With each technical achievement, the material condition of social man expanded, but nowhere in this discussion does Lucretius indicate that social man had achieved happiness.

By now people were living their lives surrounded by sturdy fortifications, and the land was divided up and marked out for cultivation. The deep sea was aflower with the flying sails of ships and already they had confederates and allies under formal treaties, at the time when poets began to record human exploits in song. But the letters of the alphabet were invented only a short time before. Consequently our age cannot look back to earlier events, except insofar as reason reveals their traces.

Navigation, agriculture, city walls, laws, arms, roads, clothing, and all other practical inventions as well as every one of life's rewards and refinements, poems, pictures, and polished statues of exquisite workmanship, all without exception were gradually taught by experience and the inventiveness of the energetic mind, as humanity progressed step by step. Thus by slow degrees time evolves every discovery, and reason raises it up into the regions of light. People saw one thing after another become clear in their minds until each art reached the peak of perfection (Lucretius. DRN 5.1440-1456. trans. Smith).

At the beginning of Book 6, there is a short section that praises Athens for discovering farming and for establishing laws. This initial praise of Athens sums up the last section of Book 5, where the material conditions of social man were brought to their level of achievement at Lucretius' time. Immediately thereafter, Lucretius praises Epicurus for teaching the way to achieve happiness. 
He (Epicurus) saw that almost everything that necessity demands for subsistence had been already provided for mortals, and that their life was, so far as possible, established in security; he saw too that they possessed power, with wealth, honor, and glory, and took pride in the good reputation of their children; and yet he found that, notwithstanding this prosperity, all of them privately had hearts racked with anxiety which, contrary to their wish, tormented their lives without a pause, causing them to chafe and fret. ... Therefore with words of truth he purged people's minds by laying down limits to desire and fear; he explained the nature of the supreme good that is our universal goal, and indicated the way, the short and straight path, by which we might reach it (Lucretius. DRN 6.9-18, 6.23-29. trans. Smith).

I find the location of the praise of Epicurus' mission interesting in Lucretius' discussion of social development. If the intent of the Epicureans, in their discussion of justice, were some primitivism, a return to the so-called "golden age" of interpersonal interactions, then one might expect to find Lucretius invoking some sort of praise of the condition of man at one of the previous earlier stages. He does not do this. Lucretius, we have seen, does offer moral observations and moral criticism at various places throughout the discussion of the origin of civilization. But he nowhere, in this discussion, refers to any alleged "golden age". If there were an earlier stage in human development of civilization that were this alleged "golden age", then Lucretius would have commented on this. Instead, what we find is the development of the material condition of civilization, and the technical achievements of humanity. With each new development in the material conditions of civilization, new empty desires emerge. Lucretius remarks near the end of Book 5 that our material possessions and the innovation in material possessions are a source of envy.

The fact is that our present possessions, so long as we have not experienced anything more agreeable in the past, 
please us preeminently and are considered to be the best; but when something superior is subsequently discovered, the new invention usually ousts all the old things and alters our feelings towards them. Thus acorns came to be disliked; thus those beds strewn with grass and heaped high with leaves were abandoned. Thus too the clothing of wild beasts' skins fell into contempt; and yet I suppose that, at the time of its discovery, it excited such envy that its first wearer was waylaid and slain, even though, after all that, the murderers, in squabbling over the garment, ripped it to pieces and besmeared it with blood so that it was ruined and rendered valueless. Then it was skins, now it is gold and purple that plague human lives with cares and weary them with war. And here, I think, the greater blame rests with us today. For whereas the children of earth were tormented by cold when they had no skins to cover their naked bodies, it is no hardship for us to go without robes of purple patterned with great goldembroidered figures, provided that we have the protection of some common garment. And so human beings never cease to labor vainly and fruitlessly, consuming their lives in groundless cares, evidently because they have not learned the proper limit to possession, and the extent to which real pleasure can increase. And it is this ignorance that has gradually carried life out into the deep sea and has stirred up from the depths the mighty boiling billows of war (Lucretius. DRN 5.1412-1435. trans. Smith).

The insistence that the Epicureans were some sort of primitivists has led some to take rather strange views. This can be seen in a recent article by David Blickman. David Blickman, in "Lucretius, Epicurus and Prehistory," has argued that the primitivist view can be found in the section on music. In this section, Blickman claims that music $(5.1379-1411)^{10}$ was known to primitive people. Lucretius' treatment of music is far beyond its practical value. Blickman uses this extended treatment of music as evidence of Lucretius' primitivism. His argument rests on two 
factors. First, Lucretius was rushing to finish a long book of this poem, and Lucretius did not organize his material very well." Second, the positive value given to references to forests (silvestre) ${ }^{12}$ indicate the return to nature element of alleged Lucretian primitivism. Blickman uses the references to forests and woodland peoples and the pastoral nature of the scenery of this passage to support the notion of a kind of primitivism attributable to Epicurean social theory. Blickman, also, relies on the gentleness of nature to provide for the basic needs of primitive humans for food and water (5.937-952) and to the pastoral calmness found in the description of the shepherds entertaining themselves after a meal with song and dance.

I do not deny that Lucretius' description of the shepherds enjoying song and dance isn't a vivid one. However, Lucretius does call these woodland folk "shepherds" implying that they have domesticated some animal over which they are tending. As well, we have a description of people coming together for the purpose of entertainment after a joint meal. This passage, hence, implies a social context, and the setting of these dinners follows from the stage of human development under consideration. Besides, in the other passages describing primitive humans, we do not get any indication that joint meals were possible. In fact, the description of primitive humans is one in which cooperation does not occur. In fact, Lucretius explicitly denies that cooperation between primitive humans was possible.

They were unable to look to the common interest, and had no knowledge of the mutual benefits of any customs or laws. Individuals instinctively seized whatever prize fortune had offered to them, trained as they were to live and use their strength for themselves alone. [(Lucretius, DRN 5. 959-962) trans. Smith]

The only interaction between primitive humans that Lucretius explicitly mentions is for the purpose of obtaining sex.

An argument Blickman could have made is Lucretius does refer to these woodland people who invented music as "children 
of the earth." This designation only occurs three times in Book 5, and two of these are in the discussion of music. ${ }^{13}$ This is also the designation of primitive humans slightly modified at 5.926, where Lucretius calls primitive humans "children of the tough earth." In spite of this similar designation, I argue that this passage does not justify the primitivist position. Although the people in this passage are enjoying music and dance, the type of pleasure they are enjoying is kinetic pleasure, and not katastematic pleasure. Even though the people in this scene are not harming one another, this passage only serves to explain the origin of music and dance. I suggest this passage on music serves as a balancing scene in the poem to the vivid imagery of warfare that preceded it, and is not the ideal of the so-called "golden age." It might be tempting to say that through the enjoyment of music and dance we can return to this state of nature and shed off the ills of society all together. Rather, through cooperative socializing, we might have a venue through which our kinetic pleasures might further enhance our experience of the telos. I think that even though Lucretius refers to these woodland people enjoying music as "children of the earth," the modification he introduces here from "children of the tough earth" to "children of the earth" is important. By becoming social, human nature changed. There is no "going back."

Hence, as we can see from the above, all attempts to locate the "golden age" in Lucretius account of the origin of human civilization fail. This is crucial, because, in order for the primitivist thesis to be successful, it must identify this "golden age" in some part of Lucretius' account. As we have seen from the above, Lucretius does not identify any of these stages as being superior to any other with respect to achieving the Epicurean telos. That is why the short section at the beginning of Book 6 is important. That section finishes off Lucretius' discussion of human social development. And it is at that point where the Epicurean "mission" not only takes place, but can take place. This is consistent with the materials we see in Epicurus' Letter to Menoeceus, where Epicurus presupposes that Menoeceus has found a way to secure the basic needs by living in a community. If our basic needs are 
better satisfied by living in a community, we must conclude that we should reject this primitivist thesis.

\section{Notes}

1. An Epicurean philosopher who had his works inscribed on a stone wall in a public colonnade in central Turkey in the second century CE.

2. Diogenes of Oenoanda. New Fragment 21 col. 1, $4 \mathrm{ff}$. in Thirteen New Fragments of Diogenes of Oenoanda. translated by Anthony Long, and reprinted in "Pleasure and Social Utility, The Virtues of Being Epicurean" in Aspects de la Philosophie Hellénistique. Tome XXXII. Fondation Hardt: Vandoevres: Geneve. 1985. p. 314-315. The remainder of the passage is as follows: For all things will be full of justice and mutual love (philallelia), and there will come to be no need of fortifications or laws and all the things which we contrive on account of one another.

3. Benjamin Farrington. The Faith of Epicurus. Weidenfeld and Nicolson: London. 1982. p. 27

4. I explore and develop an interpretation of Epicurus' views on friendship and justice in my dissertation entitled: Just Friends: Justice and Friendship in the Social Theories of Aristotle and Epicurus. In particular, see chapters 5 and 6 of the above.

5. James H. Nichols. Epicurean Political Philosophy: The De Rerum Natura of Lucretius. London, United Kingdom. Cornell University Press. 1976. p. 13-14.

6. Diogenes Laertius (X: 28) lists two works written by Epicurus that would bear on this subject. Peri Dikaiosune kai ton allon areton (On justice and the other virtues) and Peri Basileais (On Kingship). Both of these works have been lost.

7. For the purpose of this paper, I define the katastematic pleasure, the Epicurean telos, as the lack of pain in the body and the lack of trouble in the soul. For further discussion of this concept, see Cooper, John. "Pleasure and Desire in Epicurus". Reason and Emotion. Princeton, New Jersey. Princeton University Press. 1999. Purrinton, Jeffrey. "Epicurus on the Telos". Phronesis. 
Vol 38. No. 3. p. 281-320. 1993.; and Striker, Gisela. "Ataraxia: Happiness as Tranquillity". Reprinted in Essays on Hellenistic Epistemology and Ethics. Cambridge University Press: Cambridge. 1996.

8. VS 67. "A free life cannot acquire great wealth because the task is not easy without slavery to the mob or those in power; rather, it already possesses everything in constant abundance. And if it does somehow achieve great wealth, one could easily share this out in order to obtain the good will of one's neighbors". $K D$ 21. "He who has learned the limits of life knows that it is easy to provide that which removes the feeling of pain owing to want and make one's whole life perfect. So there is no need for things which involve struggle."

9. David Blickman. "Lucretius, Epicurus and Prehistory". Harvard Studies in Classical Philology. Vol 92. 1989. p. 157-191.

10. People imitated with their mouths the liquid warblings of birds long before they were able to join together in singing melodious songs with pleasure to the ear. And it was the whistling of the zephyr in the cavities of reeds that first taught country folk to blow into hollow stalks. Then little by little they learned the sweet notes that ripple from the plaintive pipe as the player's fingers strike the stops-the pipe invented in pathless woods and forest glades, in the solitary spots where shepherds rest in the open air. With this music they would soothe and charm their hearts after they had eaten their fill; for that is the time when everything affords pleasure. So they would often lie in friendly company on velvety turf near a running brook beneath the branches of a tall tree and provide their bodies with simple but agreeable refreshments, especially when the weather smiled and the season of the year embroidered the green grass with flowers; for then the rustic muse was at its best. Then, prompted by playful gaiety, they would deck their heads and shoulders with garlands of interwoven flowers and foliage and move their limbs clumsily in an unrhythmical dance, striking mother earth with clumsy feet. These performances would provoke smiles and peals of pleasant laughter, because all such pastimes, being new and wonderful, had a greater effect at that time. And the wakeful would find ready consolations for 
sleeplessness in guiding their voices through many modulations of a song in running over the reeds with pursed lips. This old tradition is still kept by watchmen today; and although they have learned to keep time, they do not derive any more pleasure from their music than did those woodland folk, the children of the earth. (Lucretius. DRN 5.1379-1411 [trans. Smith]). I provide the entire passage here for two strategic reasons. First, although Blickman uses this passage to support his interpretation, he does not quote it in its entirety. I find this odd. Second, even though this is a peaceful scene, with people in the woods enjoying music, we do not see Lucretius identifying this as the 'golden age' or the Epicurean way of life. As we have seen above, if Lucretius did think this was the way to live, he would have made one of his many moral comments. The absence of any sort of moral comment, I think, dismisses even this passage as evidence of the 'golden age'. An alternative understanding of this passage could be developed as follows. Lucretius seems to approve of this type of activity. It is social, and looks like a promising development in human social evolution. There are, however, expected dangers inherent in it, e.g., becoming decedent or encouraging envy. Unfortunately, for the purposes of this paper, I cannot develop this interpretation here.

11. Elizabeth Asmis, in "Rhetoric and Reason in Lucretius" American Journal of Philology Vol 104, No 1. 1983, has recently challenged the notion that Lucretius rushed to finish the poem, and in turn, was a "sloppy" writer. Asmis argues that Lucretius has fashioned the philosophical doctrines of Epicurus into unified essays which are heavily influenced by contemporary rhetorical theory, and which are designed at the same time to display the logical coherence of Epicurus' philosophical system as a whole. In reorganizing Epicurus' doctrines as rhetorical compositions, Lucretius continually anticipates doctrines which are proved later on in the sequence of arguments. While these would be viewed as logical disturbances in a purely logical tract, in the context of Lucretius' own rhetorical style of composition they are components of a whole, into which they fit perfectly logically. More precisely, Lucretius often lifts conclusions from a later context of argument in order to clarify and strengthen an earlier sequence of argument, 
without, however, illogically using these conclusions to prove them later; and what accounts for this procedure is that Lucretius takes the logical coherence of his doctrines as worked out in advance and makes it his goal to defend his doctrines in well rounded essays that persuade. Although Asmis applies this rhetorical style of anticipation only to her analysis of Books 1-3 of $D R N$, she suggests that the whole poem should be so read. I find this use of anticipation and elaboration a useful way of integrating these longer "set pieces" in Lucretius. The attention to rhetorical practices when Lucretius is writing reminds us that this is a poem and not a treatise, and helps us understand the organizational structure of the topics presented in the poem as a whole.

12. A few of the references cited by Blickman are: $D R N 5.948$; 5. 955-957; 5.962; 5. 970-972.

13. The designation "children of the earth" occurs at lines 5.1411 and 5.1426.

\section{BIBLIOGRAPHY}

\section{Primary Texts}

Arrighetti, Graziano. Opere / Epicuro. Torino: G. Einaudi. 1973. Auricchio, Francesca Longo. Ermarco Frammenti. Naples, Italy:

Istituto Italiano Per Gli Studi Filosofici. Vol. 7. 1988.

Chilton, C.W. Diogenes of Oenoanda, the Fragments. London, England: Oxford University Press. 1971.

Inwood, Brad and Gerson, L.P. Hellenistic Philosophy Introductory

Reading, 2nd ed. Indianapolis, Indiana: Hackett Publishing Company. 1997.

Laertius, Diogenes. Lives of Eminent Philosophy, Volume II, Cambridge Massachusetts: Harvard University Press. 1925. Long, A.A. and Sedley, D.N. The Hellenistic Philosophers, Vol 1

\& 2. Cambridge, England: Cambridge University Press. 1987. Lucretius. On the Nature of Things. trans John Selby Watson. New York, New York: Prometheus Books. 1997. 
Lucretius. On the Nature of Things. trans. W.H.D.Rouse revised by Martin F. Smith. Loeb Classical Library. Cambridge, Massachusetts: Harvard University Press. 1982.

Oates, Whitney. The Stoic and Epicurean Philosophers. The Complete Extant Writings of Epicurus, Epictetus, Lucretius, and Marcus Aurelius. Random House: New York. 1940.

\section{Secondary Literature}

Adkins, A.W. H. Moral Values and Political Behavior in Ancient Greece: From Homer to the End of the Fifth Century. London: Chatto and Windus. 1972.

Annas, Julia. The Morality of Happiness, New York, New York: Oxford University Press, 1993.

Armstrong, John. "Epicurean Justice." Phronesis. Vol 42, 1997. p. 324-334.

Asmis, Elizabeth. "Rhetoric and Reason in Lucretius". American Journal of Philology. Vol 104 No 1. 1983. p. 36-66.

Bailey, Cyril. The Greek Atomists and Epicurus, Oxford, England: The Clarendon Press, 1928.

Blickman, David. "Lucretius, Epicurus and Prehistory". Harvard Studies in Classical Philology. Vol 92. 1989. p. 157-191.

Chilton, C.W. "The Epicurean Theory of the Origin of Language: A Study of Diogenes of Oenoanda, Fragments X and XI (W)". American Journal of Philology. Vol 83, 1962. p. 159-167.

Clay, Diskin. "Individual and Community in the First Generation of the Epicurean School", Syzetesis. 1: p. 255-279.

Clay, Diskin. Paradosis and Survival, Three Chapters in the History of Epicurean Philosophy. Ann Arbor, Michigan: The University of Michigan Press, 1998.

Cooper, John M. Reason and Emotion. Princeton, New Jersey. Princeton University Press. 1999.

Cooper, John M. "Pleasure and Desire In Epicurus." in Cooper. 1999.

Chroust, Anton Hermann. "The Philosophy of Law of the Epicureans" The Thomist. Vol 16, 1953. p. 82-117 and 217267. 
De Lacy, Phillip. "Limit and Variation in the Epicurean Philosophy. Phoenix. Vol 23. 1969. p. 104-113.

DeWitt, Norman. Epicurus and His Philosophy. Reprinted by

Greenwood Press Publishers. Westport: Conneticut. 1973.

Originally published in 1954 by University of Minnesota Press. Denyer, Nicholas. "The Origin of Justice", Syzetesis. p. 133-152. Erler, Michael and Schofield, Malcolm. "Epicurean Ethics", from

Cambridge History of Hellenistic Philosophy. Cambridge,

Great Britain: Cambridge University Press, 1999.

Farrington, Benjamin. The Faith of Epicurus. Weidenfeld and Nicolson: London. 1982.

Furley, David. "Lucretius the Epicurean: On the History of Man", in Lucrèce: Huit exposés suivis de discussions par David Furley (et al.). Foundation Hardt: Geneve. 1978. p. 1-27.

Goldschmidt, Victor. "La théorie épicurienne du droit", Science and Speculation, ed J. Barnes, J. Brunschwig, M. Burnyeat, M. Schofield, Cambridge Massachusetts, 1982. p. 304-326

Guyau, M. Le Morale D'Épicure et ses Rapports avec les Doctrines

Comtemporaines. Librairie Félix Alcan: Paris. 1910.

Koen, Avraam. Atoms, Pleasure, Virtue: The Philosophy of

Epicurus. American University Studies, Series 5. Vol 152.

Peter Lang Publishing, Inc. New York. 1995.

Long, Anthony A. "Chance and Natural Law in Epicureanism". Phronesis. Vol 22, No 1. 1977. p. 63-87.

Long, Anthony A. Hellenistic Philosophy, Stoics, Epicureans,

Sceptics. Berkeley and Los Angeles, California: University of California Press, 1986.

Long, Anthony A. "Pleasure and Social Utility, The Virtues of Being Epicurean" in Aspects de la Philosophie Hellénistique. Tome XXXII. Fondation Hardt: Vandoevres: Geneve. 1985. Merlan, Philip. "Lucretius-Primitivism or Progressivist". Journal of the History of Ideas. Vol 11, Issue 3. 1950 p. 364-368.

Mistis, Philip. Epicurus' Ethical Theory, The Pleasures of Invulnerability. Ithaca, New York: Cornell University Press, 1988.

Morel, Pierre-Marre. "Épicure L'Histoire et Le Droit", Revue des Etudes Anciennes. p. 393-411. 
Müller, Reimer. "Konstituierung und Verbindlichkeit der Rechtsnormen bei Epikur." In Syzetesis.

Nichols, James H. Epicurean Political Philosophy: The De Rerum

Natura of Lucretius. London, United Kingdom. Cornell University Press. 1976.

Obbink, David. "Hermarchus Against Empedocles". Classical Quarterly. Vol 38. No. 2. 1988. p. 428-435.

O'Keefe, Timothy. "Would a Community of Wise Epicureans Be

Just?" Ancient Philosophy. Vol 21. 2001. p. 133-146.

Sedley, David. Lucretius and the Transformation of Greek Wisdom.

Cambridge, United Kingdom: Cambridge University Press, 1998.

Sedley, David. "Theophrastus and Epicurean Physics". in Theophrastus: Reappraising the Sources. 1998. p. 331-354.

Smith, Martin. "More New Fragments of Diogenes of Oenonanda" in Cahiers de Philologue: Etudes sur L'Epicurisme Antique. Publications de L'Université de Lille. 1976.

Smith, Martin. "Excavations at Oinoanda 1997: the new Epicurean texts". Anatolian Studies. Vol 44. 1998. p. 125-165.

van Ophuijsen, Johannes $M$. and van Raalte, Marlein. Theophrastus: Reappraising the Sources. New Brunswick, New Jersey: Transaction Publishers. 1998.

Vander Waert, P.A. "The Justice of the Epicurean Wise Man." Classical Quarterly. Vol 37, 1987, p. 402-422.

Vander Waerdt, Paul. "Hermarchus and the Epicurean Genealogy of Morals". TAPA. Vol 118, 1988. p. 87-106. 